\title{
Prinsip-Prinsip Perundangan Islam: Konsep Dan Aplikasinya Dalam Pentadbiran Pandemik Covid-19 Di Malaysia
}

\section{Masyitah binti Mohd Zainon}

Pensyarah, Kulliyyah Syariah \& Undang-Undang, Universiti Islam Antarabangsa Sultan Abdul Halim Mu'adzam Shah Malaysia. (UniSHAMS)

masyitahzainon@unishams.edu.my

Ahmad Hussein Abdulshakoor Siraji

Pensyarah, Kulliyyah Syariah \& Undang-Undang, Universiti Islam Antarabangsa Sultan Abdul Halim Mu'adzam Shah Malaysia. (UniSHAMS) ahmadsiraji@unishams.edu.my

\section{Mohamed Fathy Mohamed Eletrebi}

Pensyarah Kanan, Kulliyyah Syariah \& Undang-Undang, , Universiti Islam Antarabangsa Sultan Abdul Halim Mu'adzam Shah Malaysia. (UniSHAMS) fathyeletrebi@unishams.edu.my

\begin{abstract}
Abstrak
Prinsip-prinsip perundangan Islam merupakan di antara faktor yang menyumbang kepada pencapaian Maqasid Syariah. Ia berkesan merealisasikan Islam sebagai satu sistem kehidupan yang unggul dan sempurna. Hal ini kerana setiap peraturan undang-undang yang digubal bukan sahaja berasaskan jaminan kemaslahatan, bahkan juga penolakan mafsadah daripada masyarakat. Ketika situasi negara Malaysia adalah membimbangkan ekoran pandemik Covid-19, kerajaan telah mengambil pelbagai inisiatif dan tindakan dalam usaha memutuskan rantaian wabak. Dalam kajian ini, terdapat lima pentadbiran pandemik pada tahun 2020 telah dianalisis menggunakan prinsip-prinsip perundangan Islam. Data-data dari (Kementerian Kesihatan Malaysia), (Majlis Keselamatan Negara), (Majlis Kebangsaan Bagi Hal Ehwal Ugama Islam Malaysia), (Kementerian Pendidikan Malaysia) dan (Jabatan Kehakiman Syariah Malaysia) telah dihimpun secara induktif serta dianalisis menggunakan pendekatan analisis kandungan. Hasil kajian menunjukkan bahawa kerajaan Malaysia telah pun menerapkan dengan baik prinsip-prinsip perundangan Islam sekaligus mencapai maqasid syariah yang paling utama. Kajian lanjutan perlu dilaksanakan bagi menyatukan sokongan masyarakat terhadap agenda perlindungan keselamatan rakyat dan negara. Kata kunci: Solat, Pesakit, Pembangunan Digital, Kajian dan Malaysia.
\end{abstract}

Kata Kunci: Sadd Al-Dharā’I’, IbțāL Al-Ḥiyal, Al-IstiḥsāN, Al-In'ițāF Wa Al-Inkisyāf, Covid-19 


\section{Prinsip-Prinsip Perundangan Islam: Konsep Dan Aplikasinya Dalam Pentadbiran Pandemik Covid-19 Di Malaysia}

\section{Pengenalan:}

Menurut Ibn Asyur, sebelum kemunculan ilmu Usul Fiqh, prinsip-prinsip umum perundangan Islam telah pun difahami dengan baik oleh para mujtahid dan fuqaha. Hal ini kerana merekalah yang merupakan individu yang bertanggungjawab melaksanakan ketetapan hukum syarak serta sumber-sumber dalil yang menyokongnya. Selain itu, mereka juga telah menjalankan proses penelitian dan semakan yang mendalam dalam pembinaan hukum dan pemetaannya dengan dalil masing-masing. Justeru, kematangan para mujtahid telah berhasil menemukan dan membina prinsip-prinsip perundangan Islam serta merangkumkan pelbagai hukum dan masalah ke dalamnya.(Ibn Asyur:2004) Ia sekaligus dapat membantu memudahkan proses instinbat dan analisis hukum fiqh setelah mereka mewujudkan dasar-dasar ke atas prinsip-prinsip tersebut berlandaskan kefahaman mereka terhadap illah dan faktor penetapan hukum serta hikmah memperundangkannya. Lantaran itu, ilmu berkaitan prinsip-prinsip perundangan Islam ini telah menduduki tempat yang penting dalam fiqh Islam, terutamanya dalam menyelesaikan sebahagian besar isu-isu kontemporari yang tidak terdapat sumber hukum yang jelas daripada nas al-Quran dan al-Sunnah.

\section{Konsep Prinsip-Prinsip Perundangan Islam}

Prinsip-Prinsip Perundangan Islam seperti Masalih Mursalah, 'Urf, Syar' Man Qablana, Sadd al-Dharā 'i', al-Istihsān, Qawl al-Sahabi dan banyak lagi merupakan sumber sekunder dalam perundangan Islam. Ia tidak kurang pentingnya sebagai rujukan terutamanya dalam menangani isu-isu semasa khususnya melibatkan pentadbiran sebuah negara. Justeru, konsepnya telah diperkenalkan oleh ramai sarjana Islam melalui pelbagai kajian masing-masing

Pada dasarnya, perkataan prinsip-prinsip di dalam bahasa Arab bermaksud "Al-Qawa id". Ia adalah perkataan jamak kepada "al-qa'idah" yang memberi maksud asas binaan. Menurut istilah fuqaha' qawaid mempunya tiga pengetian. Pertama, ia bermaksud hukum kebanyakan yang bukan holistik yang bersesuaian dengan kebanyakan perincian sesuatu perkara di bawahnya bagi mengetahui hukum. Kedua, ia bermaksud persoalan yang 


\section{Masyitah binti Mohd Zainon, Ahmad Hussein Abdulshakoor Siraji, Mohamed 24 Fathy Mohamed Eletrebi}

bersifat holistik yang bersesuaian yang perincian setiap perkara di bawahnya. Ketiga, ia bermaksud perkara holistik yang bersesuaian dengan setiap perincian di bawahnya (Hanief:2021). Justeru, prinsip boleh disimpulkan sebagai suatu hukum holistik yang terangkum pelbagai perkara-perkara cabang yang dapat digunakan sebagai sumber hukum atau hujah sokongan (Hanief:2021).

Manakala perkataan perundangan Islam di dalam bahasa Arab bermaksud "al-Syariyyah". Ia adalah kata nama mu' annas yang dinisbahkan kepada "syara". Syara' dan Syariah bermaksud agama yang telah ditetapkan oleh Allah S.W.T kepada hambanya yang terdiri daripada pelbagai hukum dan undang-undang (al-Qurtubi:1964). Justeru, gabungan daripada perkataan prinsip-prinsip (al-qawaid) dan perundangan Islam (al-syar'iyyah) telah menjadi satu istilah baharu yang mewakili satu disiplin ilmu yang baharu. Menurut al-Zarqa', ia merupakan prinsip yang bersifat undang-undang yang diambil daripada sumber-sumber perundangan Islam yang ringkas yang mengandungi peraturan umum bagi isu-isu yang bertakluk di bawahnya. Selain itu, menurut beliau lagi meskipun prinsip-prinsip tersebut bersifat umum tetapi ia memainkan peranan yang penting dalam menyelesaikan sebahagian besar hukum fiqh yang mana tidak ada sumber hukum yang jelas di dalam al-Quran dan al-Sunnah (al-Zarqa': 1998).

Dalam membincangkan permasalahan berkaitan aplikasi Prinsip-Prinsip Perundangan Islam dalam pentadbiran pandemik Covid-19 di Malaysia, terdapat pelbagai kajian lepas yang telah menyentuh berkaitannya. Antaranya adalah kajian Muneer, Izzuddin, Abdul Halim dan Nur Hidayat. Kajian Munir telah mengaplikasi empat prinsip perundangan Islam iaitu Al-Masyaqqah Tajlib Al-Taysir, Al-Darar Yuzal, Al-Darurat Tubihu AlMahzurat dan Tasarruf Al-Imam 'Ala Al-Raiyyah Manutun Bi AlMaslahah dalam menghadapi Covid-19 (Muneer:2020). Manakala kajian Izzuddin telah mengaplikasi lima prinsip iaitu Al-Umur Bi Maqasidiha, Al-Yaqin La Yuzal Bi Al-Syak, Al-Masyaqqah Tajlib Al-Taysir, Al-Darar Yuzal dan Al-'Adah Muhakkamah (Izzudin:2020). Selain itu, kajian Nur Hidayat adalah lebih kepada meneliti perspektif Islam terhadap pelaksanaan Perintah Kawalan Pergerakan (PKP) di beberapa peringkat dan situasi di Malaysia (Nur Hidayat:2020), manakala kajian Abdul Halim adalah satu tinjauan terhadap tahap kefahaman masyarakat terhadap peranan Maqasid Syariah dalam menangani Covid-19 (Abdul Halim: 2021). Justeru, kajian ini lebih memfokuskan kepada aplikasi kaedah yang berlainan pada aspek yang lebih menyeluruh termasuk menganalisis 


\section{Prinsip-Prinsip Perundangan Islam: Konsep Dan Aplikasinya Dalam Pentadbiran Pandemik Covid-19 Di Malaysia}

pentadbiran Prosedur Operasi Standart (SOP) kerajaan Malaysia dari perspektif pencapaian Daruriyat al-Khams.

\section{Prinsip-Prinsip Perundangan Islam}

\section{Prinsip Sadd al-Dharā'I' (Langkah Pengawalan).}

Sadd al-Dharā ' $i$ 'tersusun dari dua perkataan iaitu al-sadd dan al-dharā $i$ '. Sadd al-Dharā ' $i$ ' di sisi ulama usul ialah menutup jalan yang membawa kepada implikasi yang buruk manakala Fath al-Dharā ' $i$ ' pula ialah membuka jalan yang membawa kepada maslahat. Jadi apakah yang dimaksudkan dengan Sadd al-Dharā ' $i$ ' dan apakah kaitannya dengan Fiqh al-Mustaqbal (Fikah Masa Depan)?

Sadd al-Dharā ' $i$ ' dari sudut bahasa Arab ialah: sadd bermaksud batasan dan pemisah antara dua benda (Al-Fayyūmī). Adapun al-dharā 'i' ialah jamak dari perkataan al-dharì' $a h$ yang berasal dari kata akar dhara'a yang membawa maksud memanjang, meluas dan bergerak ke hadapan. Kesimpulannya, al-dharì'ah ialah jalan yang boleh menyampaikan kepada sesuatu samada secara fizikal atau maknawi, baik ataupun buruk (AlBardīsī, 1969). Sadd al-Dharā 'i’’ dari sudut istilah ialah menegah daripada melakukan perbuatan-perbuatan yang dibolehkan (pada asalnya) yang dapat mendorong kepada perkara yang dilarang syarak, juga dikatakan memutuskan unsur daripada jalan-jalan kerosakan dengan menegahnya. Ini adalah makna khas setelah menambah perkataan al-dharā ' $i$ ' kepada sadd, adapun al-dharā ' $i$ ' dengan maknanya yang umum merangkumi Sadd al-Dharā 'i’ dan Fath al-Dharā 'i’'.

Makna Fath al-Dharā $i '$ ' ialah membolehkan jalan-jalan yang membawa kepada setiap keperluan dan kebaikan dan Sadd al-Dharā ${ }^{\prime} ’$ : ialah menegah jalan-jalan yang membawa kepada setiap kerosakan dan kejahatan (Al-Futūhīi, 1997). Imam al-Qarāfî menyebut di dalam kitabnya al-Furūq akan makna al-dharā $i$ ': "Ketahuilah bahawa al-dharì'ah itu sepertimana diwajibkan menutupnya maka diwajibkan juga membukanya dan disunatkan, dimakruhkan, serta diharuskan kerana sesungguhnya aldharì'ah itu ialah al-wasīlah 


\section{Masyitah binti Mohd Zainon, Ahmad Hussein Abdulshakoor Siraji, Mohamed 26 Fathy Mohamed Eletrebi}

Al-Syāțibī berpendapat di dalam kitabnya al-Muwāafaqāt membezakan antara $a l$-dharā ' $i$ ' dan al-wasā 'il dari sudut istilah kerana pendapatnya alwasā 'il ialah yang membawa kepada kemaslahatan manakala al-dharā ' $i$ ' ialah yang membawa kepada kerosakan. Diketahui yang demikian itu pada katanya: "Hakikatnya (al-dharā $i$ ') ialah mengguna jalan maslahat (mașlahah) sebagai cara untuk mendatangkan kerosakan (mafsadah) (AlSyātịīi)".

Pendapat fuqaha dan ulama usul mengesahkan kaitan antara al-dharā ' $i$ dan mustaqbal (masa depan) dan fikahnya. Sebilangan dari mereka menganggapnya sebagai salah satu asas daripada usul fikah seperti Imam Malik dan Imam Ahmad, sebagaimana Imam Malik memutuskanya dalam kebanyakan bab fikah (Al-Syāțibī) dan Imam Ibn al-Qayyim menganggapnya sebagai satu perempat daripada taklif (Ibn al-Qayyim, 1987) sementara Imam Abu Hanifah beramal dengannya manakala Imam Syafii terkadang beramal dengannya dan terkadang tidak kerana beramal dengan kaedah usuliyyah yang lain (Biltājī, 1420h). Ini menegaskan bahawa beramal dengan Sadd al-Dharā ' $i$ ' adalah proses yang berterusan dengan fikah, dan mengesahkan kaitan dan perkembangannya dengan Fiqh al-Mustaqbal (Fikah Masa Depan) selama mana masalah fikah itu berkait dengan kehidupan dan peristiwa dan perkembangannya.

\section{Prinsip Ibțāl al-Hiyal (Membatalkan Helah-Helah).}

Al-Hiyal ialah jamak perkataan ḥillah. Makna al-ḥ̄lah, al-iḥtiyāl, dan altahayyul: ialah kepintaran, pandangan yang bagus, dan mampu bertindak dengan tepat, tetapi perkataan al-hịlah banyak digunakan pada melakukan kejahatan. Sebahagian daripada maknanya (al-hīlah) dari sudut bahasa Arab dan uruf: ialah makar, tipu, dan licik. Kebanyakannya pada perbuatan yang dicela dan terkadang ditujukan juga pada perbuatan yang dipuji seperti firman Allah Taala:

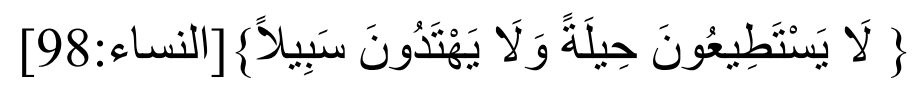

Maksudnya: "yang tidak berdaya upaya mencari helah (untuk melepaskan diri) dan tidak pula mengetahui sesuatu jalan (untuk berhijrah).’'[Al-Nisā':98] (Lisān al- 'Arab; Al-Mu'jam al-Wasīt, \& Al-Miṣbāh al-Munìr). 


\section{Prinsip-Prinsip Perundangan Islam: Konsep Dan Aplikasinya Dalam Pentadbiran Pandemik Covid-19 Di Malaysia}

Menurut al-Syāțibī: "Sesungguhnya hakikat al-hiyal yang masyhur itu ialah melakukan perbuatan yang jelas dibolehkan untuk membatalkan hukum syarak dan mengubahnya kepada hukum yang lain, maka kesan beramal padanya merosakkan asas-asas syariat (Al-Muwāfaqāt)".

Diteliti daripada kata-kata usuliyyin akan mendapati apa yang dilakukan oleh seorang mukalaf dengan helah yang membawanya - dalam waktu terdekat - kepada tindakan yang dilarang, maka asal larangan tindakan tersebut bermula dari apa yang kembali ia kepada natijah pengharaman dengan menerima perbezaan antara al-dharí'ah dan al-hìlah, bahawa aldharì'ah itu adalah cara untuk mencapainya, tetapi al-h̄ilah (muslihat) itu dilarang kerana tujuannya menghilangkannya asas-asas dan ketentuan syarak, tetapi al-dharī'ah tidak semestinya ditujukan untuk itu, bahkan aldharì'ah lebih umum daripada al-hīlah yang sering digunakan dalam akad. Jadi ulama berkata: "Al- 'Ibrah fi al- 'uqūd bi al-maqāșid wa al-ma' ānī là al-alfāz wa al-mabān̄̄ (Apa yang diambil kira dalam sesuatu akad ialah maksud dan maknanya, bukan pada lafaz dan bentuk perkataannya)".

\section{Prinsip al-Istihsān (Penyimpangan Daripada Suatu Dalil Kias Yang Nyata Kepada Dalil Yang Tidak Nyata).}

Istihsan dari sudut bahasa Arab ialah asal daripada perkataan al-husn (baik) lawan bagi perkataan al-qubh (buruk) atas wazan is-tif-'ál, yang diitlakkan kepada tiap-tiap perkara yang nafsu cenderung kepadanya. Apabila disebut: istahsana al-syai memberi maksud menganggap sesuatu perkara itu baik samada maknawi atau fizikal (Lisān al- 'Arab; Al-Mu'jam al-Wasīt, \& Al-Miṣbāḥ al-Munīr).

Istihsan dari sudut istilah: yakni berpaling di dalam menghukum sesuatu masalah daripada masalah-masalah yang sebanding dengannya kerana ada dalil yang khusus terdiri dari al-Quran dan hadis. Ditakrifkan juga: sebagai dalil yang kukuh berada dalam diri mujtahid yang amat sukar untuk diungkapkan. Takrif lain: ialah beramal dengan dalil yang lebih kuat daripada dua dalil. Takrif seterusnya: ialah berpaling daripada menghukum satu masalah dengan hukum yang sama dengan bandinganbandingannya kepada hukum yang bertentangan dengannya kerana wujud dalil yang lebih kuat (Hamīdān, 2006). 


\section{Masyitah binti Mohd Zainon, Ahmad Hussein Abdulshakoor Siraji, Mohamed 28 Fathy Mohamed Eletrebi}

Telah diketahui ulama mazhab Hanafi mengambil kira istihsan dan beramal dengannya sehingga mereka mengatakan: "Tidak ada yang bersama dengan Imam Abu Hanifah padanya". Imam Malik mengiranya sembilan persepuluh ilmu. Al-Sarkhasī berkata: Istihsan ialah meninggalkan qias, dan mengambil apa yang paling sesuai untuk orang, dan dikatakan: istihsan ialah adalah mencari kemudahan dalam hukuman pada sesuatu yang memenuhi khas dan umum padanya, dan juga dikatakan mengenainya: istihsan ialah mengambil dengan kesenangan dan mencari kelembutan hati, dan dikatakan: mengambil dengan bertolak ansur dan mencari apa yang selesa (Al-Tajdìd Fì 'Ilm Usūl al-Fiqh al-Sunnī Fì al'Așr al-Hadīth Baina al-Naẓariyyah Wa al-Tațbīq).

Sesiapa yang memahami tabiat istihsan yang Imam Malik dan Imam Abu Hanifah katakan nescaya akan mendapati bahawa mereka tidak maksudkan dengannya suatu tambahan atau yang keluar daripada nas-nas syarak, sebaliknya ia adalah pendalilan yang wajar dari qias atau maslahat atau kaedah yang muktabar seperti Raf'u al-haraj wa al-masyaqqah (mengangkat kesusahan dan kesulitan) atau al'Urf al-mustahiqq li al'amal bih (uruf yang mesti dibuat amal dengannya) atau bagi ijmak yang boleh diteima, oleh sebab itu maka ia bukanlah seronok-seronok atau katakata mengikut hawa nafsu dan akal semata-mata. Kerana itu, al-Syātịīî berkata: "Dan jika ini adalah makna istihsan menurut Imam Malik dan Imam Abu Hanifah, maka itu sama sekali tidak terkeluar dari dalil-dalil, karena dalil-dalil tersebut mengikat satu sama lain dan mengkhususkan satu sama lain, seperti dalam dalil-dalil hadis dengan al-Quran, dan Imam Syafii tidak menolak dalil sepeti ini (Al-Syāțibī)".

Bahagian-bahagian istihsan yang usuliyyin nyatakan adalah (Rab $\vec{\imath}, 2007)$ : Istihsan dengan nas (al-Quran atau hadis), istihsan dengan ijmak, istihsan dengan maslahat, istihsan dengan qias, istihsan dengan uruf, dan istihsan dengan darurat, yang semuanya didasarkan pada kenyataan bahawa fakih melihat sesuatu yang baru yang mengalihkan pandangannya pada suatu masalah kepada hukum yang baru yang muncul kepadanya, dan ini adalah titik temu istihsan dengan Fqh al-Mustaqbal (Fikah Masa Depan) yang pembentukannya untuk menjaga maslahat, mengambil apa yang paling sesuai untuk orang, mencari kelapangan dan toleransi, dan itulah salah satu ciri syariat ini di mana Allah Taala tidak jadikan padanya kesusahan dan kesempitan, dan melepaskannya dari kekerasan dan belenggu yang ada pada yang terdahulu, dan ini menegaskan bahawa syariat mengikuti apa yang didapati dalam kehidupan pada masa kini dan masa depan daripada 


\section{Prinsip-Prinsip Perundangan Islam: Konsep Dan Aplikasinya Dalam Pentadbiran Pandemik Covid-19 Di Malaysia}

kejadian-kejadian dan perkara-perkara baru yang istihsan boleh mengadaptasinya selama tidak menghalalkan yang haram dan mengharamkan yang halal. Kerana itulah Imam Malik mengiranya sembilan persepuluh ilmu (Ḥamīdān, 2004).

Sesungguhnya adalah melihat kepada implikasi perbuatan-perbuatan itu diperakui oleh syarak yang disokong istihsan yang bertujuan untuk mencari maslahat ketika perlaksanaan hukum tersebut dengan membuat pengecualian dari kaedah-kaedah asal dan qias (Al-Ijtihād al-Tanzīlì).

\section{Prinsip al-In'itâf (Jangkaan Dari Sebab Terdahulu) wa al- Inkisyäf (Jangkaan Dari Ketersingkapan Masa Depan).}

Al-In'ițāf dan al-Inkisyāf adalah dua kaedah fikah dalam mazhab Maliki yang diasaskan untuk Fiqh al-Mustaqbal (Fikah Masa Depan) dan Fiqh al-Tawaqqu' (Fikah Jangkaan) juga banyak diperkatakan dalam bab alqaḍa dan al-diyyāt. Al-In'ițâf membawa makna al-muțāwa'ah (natijah, kesan, hasil), dan in'ațafa: bermakna miring dan cederung. Inkasyafa alsyai: bermakna nyata, jelas. Takasysyafa al-syai: seperti makna inkasyafa. Iktasyafa al-amr: bermakna menjelaskan sesuatu perkara dengan usaha (Al-Mu'jam al-Wasìt ). Syeikh al-Walāt $\bar{l}^{1}$ menyebut dua kaedah tersebut di dalam kitabnya al-Mujāz al-Wādih .

Kemudian beliau mensyarahkannya dalam kitabnya al-Dalīl al-Māhir alNāṣih Syarh al-Mujāz al-Wādih (Al-Walātī) dengan menyebut pengaplikasiannya dan cabang-cabangnya. Walaupun al-in'itāf bertentangan dengan al-inkisyāf, tetapi kaedah tersebut mengesahkan pentingnya pandangan yang kolektif antara memperkatakan sesuatu perbuatan dan melakukannya, sebab dan akibatnya, dan apa yang

${ }^{1}$ Beliau adalah al-Imām al-Syaikh al-'Allāmah Muḥammad Yaḥyā (alFaq̄ih) Bin Muhạmmad al-Mukhtār Bin al-Tālib 'AbdulLāh al-Naffā' Bin Aḥmad Hājj al-Dāwūdī al-Walātī al-Mālikī al-Asy’arī al-Syanqīî̀. Salah seorang ulama terkemuka yang menggabungkan penulisan, pengajaran, bimbingan, pendidikan syariah sejati. Penulisannya mencapai seratus buku dalam bahasa, tatabahasa, fikah dan usul fikah. Dilahirkan pada tahun 1259 Hijrah - dan meninggal $1330 \mathrm{H}$ di Chinguetti, Mauritania. 
Masyitah binti Mohd Zainon, Ahmad Hussein Abdulshakoor Siraji, Mohamed 30 Fathy Mohamed Eletrebi

kembali $^{2}$, iaitu antara al-athar al-raj' $\bar{\imath}$ (ketetapan yang dibuat selepas berlakunya sesuatu perkara) dan sesuatu yang mengungkapkannya oleh masa depan.

Para ulama mazhab Maliki telah menulis di dalam kitab mereka banyak kaedah fikah yang menjadi asas untuk futuristik dan melihat kepada implikasinya, termasuklah apa yang disebutkan oleh al-Muqrī dalam kitabnya al-Qawā'id (Al-Muqrī), al-Zaqqāq dalam al-Manhaj alMuntakhab yang disyarahkan oleh Syeikh Ahmad Bin 'Alī al-Manjūr dengan menamakannya Syarh al-Manhaj al-Muntakhab ilā Qawā'id alMadhhab (Al-Manjūr). Ini adalah kaedah dan asas yang paling menonjol bagi futuristik dan Fiqh al-Ma ālāt (Fikah Implikasi), dan kita akan memasuki subjek seterusnya iaitulah pengaplikasiannya.

\section{Aplikasi Prinsip-Prinsip Perundangan Islam Dalam Pentadbiran Covid- 19 Di Malaysia}

Umum mengetahui bahawa Pandemik Covid-19 telah melanda seluruh dunia dengan jumlah kematian mencecah lebih sejuta orang di mana kematian rakyat di Malaysia sahaja berjumlah 28,576 kematian. Selain itu, Malaysia juga terus mengalami peningkatan jangkitan dan kadar kematian sehingga menyebabkan kerajaan terpaksa mengenakan pelbagai insiatif segera bagi membendung penyebaran wabak dan memutuskan rantaian COVID-19. Usaha kerajaan adalah bagi memastikan kelangsungan hidup rakyat dapat diteruskan.

Statistik semasa jangkitan COVID-19 sehingga 15 Mei 2021 yang dikeluarkan oleh Kementerian Kesihatan Malaysia (KKM) sehingga 30 Oktober 2021 melibatkan kes baharu adalah 5,854 kes (2,466,663 kes kumulatif), Kes yang memerlukan rawatan di Unit Rawatan Rapi (ICU) berjumlah 570 kes dan kes yang memerlukan bantuan pernafasan adalah 293 kes. Justeru, diantara langkah-langkah yang telah diambil oleh kerajaan dalam menangani wabak ini adalah seperti berikut:

\section{Pelaksanaan Perintah Kawalan Pergerakan (PKP)}

${ }^{2}$ Dr Muslim al-Dausarī telah mengambil kaedah ini sebagai kajian tesis Phdnya yang bertajuk Al-Taqdīrāt al-Syar'iyyah Wa Atharuhā Fī alTaq'id al-Ușūlì Wa al-Fiqhì. 


\section{Prinsip-Prinsip Perundangan Islam: Konsep Dan Aplikasinya Dalam Pentadbiran Pandemik Covid-19 Di Malaysia}

Langkah utama kerajaan adalah dengan mengumumkan pelaksanaan Perintah Kawalan Pergerakan (PKP) yang mulai berkuatkuasa pada 18 Mac 2020 sehingga 31 mac 2021 di seluruh negara. Pelaksanaan ini adalah bagi mengawal pergerakan orang awam dan menghindar pemerebakan COVID-19. Walaupun PKP menelan kos yang tinggi dan memberi kesan kepada ekonomi, tetapi ia perlu untuk dilaksanakan. Ia kemudiannya dilanjutkan sehingga 14 April 2020, seterusnya sehingga 28 April 2020, selanjutnya sehingga 12 Mei 2020 berikutan peningkatan kes jangkitan. Perintah ini dibuat di bawah Akta Pencegahan dan Pengawalan Penyakit Berjangkit 1988 dan Akta Polis 1967.

Walau bagaimanapun, pada 27 Mac 2020 Perintah Kawalan Pergerakan Diperketatkan (PKPD) dilaksanakan di beberapa kawasan tertentu di Malaysia. Ia berikutan kawasan kawasan tersebut telah menyumbang kepada jumlah jangkitan yang tinggi. PKPD kemudiannya dilanjutkan sehingga 06 Jun 2020. Antara kawasan yang terlibat adalah kawasan di negeri Johor, Selangor dan Wilayah Persekutuan Kuala Lumpur.

Pada 01 Mei 2020, kerajaan mengumumkan pula pelaksanaan Perintah Kawalan Pergerakan Bersyarat (PKPB) dengan memberi pelonggaran kepada syarat-syarat PKP tertentu secara terkawal. Ia kemudiannya digantikan dengan pengumuman pelaksanaan Perintah Kawalan Pergerakan Pemulihan (PKPP) bermula 10 Jun 2020 dan dilanjutkan sehinga 31 Disember 2020.

Kesemua Perintah Kawalan Pergerakan ini secara umumnya meliputi sekatan menyeluruh semua perjalanan rakyat Malaysia ke luar negara, sekatan kemasukan semua pelancong dan pelawat asing ke dalam negara termasuk sekatan rentas negeri seluruh negara dan rentas daerah di kawasan PKP. Selain itu, kerajaan menetapkan bahawa pergerakan rentas negeri hanya akan dibenarkan apabila kadar vaksinasi lengkap populasi dewasa mencapai 90 peratus. Oleh yang demikian, pada 2 April 2020 dilaporkan bahawa terdapat 4,189 individu telah ditangkap kerana telah melanggar perintah kawalan pergerakan di mana 1,449 individu telah dituduh di mahkamah dan dikenakan denda sehingga RM1,000 atau dipenjarakan tidak melebihi enam bulan atau kedua-duanya bagi tertuduh yang didapati tersalah. 
Masyitah binti Mohd Zainon, Ahmad Hussein Abdulshakoor Siraji, Mohamed 32 Fathy Mohamed Eletrebi

\section{Analisis Pelaksanaan Perintah Kawalan Pergerakan (PKP)}

Hasil penelitian terhadap Perintah Kawalan Pergerakan (PKP), Perintah Kawalan Pergerakan Diperketatkan (PKPD), Perintah Kawalan Pergerakan Bersyarat (PKPB dan Perintah Kawalan Pergerakan Pemulihan (PKPP) yang telah dilaksanakan dapat disimpulkan bahawa langkah proaktif kerajaan dalam melaksanakan fasa-fasa Perintah Kawalan Pergerakan telah merealisasikan maqasid pemeliharaan nyawa dengan menyekat pergerakan masyarakat ditempat yang sesak dan sempit kerana virus Covid-19 mudah berjangkit di kawasan yang tidak mempunyai pengudaraan yang baik. Selain itu, penemuan terbaharu mendapati bahawa COVID-19 juga boleh merebak melalui udara sekaligus mengundang risiko jangkitan yang lebih cepat dan meluas. Manakala dalam masa yang sama turut berlaku penularan varian Delta yang didapati 90 peratus lebih pantas merebak dari varian asal.

Selain itu, pelaksanaan Perintah Kawalan Pergerakan ini juga telah merealisasikan prinsip Sadd al-Dharī'ah iaitu menyekat penularan wabak Covid-19 melalui tindakan penguatkuasaan pemantauan pematuhan prosedur operasi standard (SOP) Perintah Kawalan Pergerakan dengan mengadakan sekatan jalan raya yang dikawal oleh Polis Diraja Malaysia (PDRM), Jabatan Sukarelawan Malaysia (RELA) dan Angkatan Tentera Malaysia (ATM) di bawah Kementerian Dalam Negeri (KDN). Malah, ia juga telah merealisasikan prinsip Ibtâl al-Hiyal melalui tindakan kompaun sebanyak rm1,000 sehingga rm10,000 yang diambil terhadap individu yang engkar bagi memberi kesedaran mengenai kepentingan pematuhan SOP Perintah Kawalan Pergerakan yang telah diwartakan.

\section{Penangguhan Aktiviti Keagamaan Di Masjid Dan Surau}

Pada 15 Mac 2020 telah berlangsung satu Mesyuarat Khas Jawatankuasa Muzakarah Majlis Kebangsaan Bagi Hal Ehwal Ugama Islam Malaysia (MKI) ekoran pengisytharan Pertubuhan Kesihatan Sedunia (WHO) bahawa penyebaran wabak COVID-19 di seluruh dunia telah mencapai paras pandemik. Mesyuarat telah bersetuju memutuskan penangguhan semua aktiviti keagamaan di semua masjid dan surau merangkumi Masjid Negeri, Masjid Daerah, Masjid Kariah dan Surau Jumaat. Penangguhan ini dilaksanakan dalam tempoh Perintah Kawalan Pergerakan dan telah dilanjutkan sehingga berakhirnya PKP. 


\section{Prinsip-Prinsip Perundangan Islam: Konsep Dan Aplikasinya Dalam Pentadbiran Pandemik Covid-19 Di Malaysia}

Bagi mengawal penularan dan jangkitan, kapasiti jemaah yang dibenarkan hadir ke masjid mestilah tidak melebihi 30 orang yang ditentukan oleh pihak berkuasa agama negeri masing-masing. Bagi jemaah yang mengidap penyakit kronik, warga emas yang berumur 70 tahun ke atas dan kanakkanak di bawah umur 15 tahun tidak dibenarkan hadir berjemaah di masjid. Solat Jumaat juga diadakan secara ringkas selama maksima 25 minit termasuk pembacaan khutbah dan penunaian solat. Sebarang kuliah agama, iktikaf dan upacara akad nikah adalah tidak dibenarkan sama sekali. Arahan penutupan masjid dan surau adalah mengikut Seksyen 18 (1) (d) Akta Pencegahan dan Pengawalan Penyakit Berjangkit 1988 (Akta 342) yang tidak membenarkan pelaksanaan apa-apa aktiviti sepanjang tempoh penutupan. Keputusan yang dibuat telah pun mempertimbangkan maslahah dan mafsadah yang lebih besar sekaligus membantu kerajaan dalam menangani penularan jangkitan.

Walau bagaimanapun, timbul pertikaian di kalangan masyarakat terhadap SOP kehadiran ke Masjid yang dilihat terlalu diperketatkan berbanding premis lain dengan mengehadkan kapasiti jemaah selain mewajibkan jemaah hadir dengan siap berwuduk, membawa sejadah, melakukan penjarakan satu hingga dua meter ketika dalam saf dan terbaharu kehadiran hanya terhad kepada jemaah yang lengkap vaksinasi COVID19. Bukan sahaja itu, malah turut dipersoalkan berhubung ketidakkeseragaman dalam pelaksanaan SOP di setiap negeri sekalipun pengurusan masjid dan surau terletak dibawah bidang kuasa negeri memandangkan kerajaan di peringkat persekutuan telah memberi kelonggaran.

\section{Analisis Penangguhan Aktiviti Keagamaan Di Masjid Dan Surau}

Hasil penelitian terhadap penangguhan aktiviti keagamaan di masjid dan surau didapati bahawa langkah kerajaan tersebut telah merealisasikan maqasid pemeliharaan agama supaya syiar Islam yang utama iaitu solat kekal diimarahkan dan diserlahkan sekalipun secara terhad dan terbatas. Ia selaras dengan ketetapan majoriti ulama Usul Fiqh dan Maqasid Syariah bahawa pemeliharaan agama tetap menduduki kedudukan yang utama berbanding pemeliharaan dharuriyyat yang lain. Walau bagaimana sekalipun, tidak dinafikan bahawa penangguhan ini secara umumnya merealisasikan maqasid pemeliharaan nyawa yang lebih utama berikutan wabak COVID-19 yang melanda. Tetapi perlu juga ditekankan bahawa 
Masyitah binti Mohd Zainon, Ahmad Hussein Abdulshakoor Siraji, Mohamed 34 Fathy Mohamed Eletrebi

pengangguhan aktiviti keagamaan di masjid dan surau sama sekali tidak dilaksanakan secara total sebaliknya hanya dihadkan fungsi keduanya susulan situasi pandemik yang masih membimbangkan.

Bahkah juga, alternatif solat di rumah telah merealisasikan prinsip alIstihsān iaitu menjamin maslahah masyarakat dengan tidak mendedahkan mereka kepada kemungkinan berlakunya jangkitan COVID-19 terutamanya kepada warga emas yang merupakan pengunjung utama masjid. Hal ini kerana semua perhimpunan yang melibatkan orang ramai termasuk di masjid dan surau turut menjadi faktor penyebaran jangkitan. Selain itu juga, prinsip Sadd al-Dharī'ah turut direalisasikan dengan mewajibkan jemaah yang hadir ke masjid dan surau mengambil langkah pencegahan bagi mengelak mudarat yang lebih besar dengan menyediakan kelengkapan solat kendiri seperti kelengkapan air berwuduk, sejadah dan telekung.

\section{Pengoperasian Mahkamah Syariah Secara Atas Talian}

Pandemik COVID-19 menyaksikan institusi mahkamah syariah juga turut terkesan apabila terpaksa menghentikan operasi perkhidmatan kehakiman kerana tidak disenaraikan sebagai perkhidmatan perlu oleh Majlis Keselamatan Negara (MKN). Penutupan semua mahkamah syariah dan perkhidmatannya adalah bermula pada 18 Mac 2020 sehingga 31 Mac 2020, 1 April 2020 hingga 14 April 2020 dan 15 April hingga 28 April 2020. Antara urusan yang ditangguh adalah semua prosedur perbicaraan dan pengurusan kes secara fizikal melibatkan semua kes mal dan jenayah. Walau bagaimanapun, pengecualian diberikan bagi pendaftaran kes-kes baharu yang yang mendesak melalui perakuan segera dengan kebenaran mahkamah.

Lanjutan daripada itu, Dewan Rakyat pada 26 Ogos 2020 telah meluluskan Rang Undang-Undang (RUU) Mahkamah Kehakiman (Pindaan) 2020 pelaksanaan perbicaraan secara atas talian, tertakluk kepada pertimbangan hakim. Pindaan tersebut sekaligus membenarkan mahkamah menjalankan prosiding kes-kes yang telah ditetapkan mengikut jadual sepanjang tempoh Perintah Kawalan Pergerakan. Perbicaraan kes secara dalam talian adalah alternatif praktikal bagi menyelesaikan masalah kes-kes segera atau tertangguh. Seperkara lagi pendekatan yang diambil dilihat mampu menjimatkan masa dan kos sekaligus menjamin penyelesaian kes dengan segera. 


\section{Prinsip-Prinsip Perundangan Islam: Konsep Dan Aplikasinya Dalam Pentadbiran Pandemik Covid-19 Di Malaysia}

Selain itu, pandemik COVID-19 telah memberi implikasi kepada peningkatan statistik kes perceraian dan kes keganasan rumahtangga pasangan beragama Islam yang berpunca daripada kehidupan yang terjejas dari segi ekonomi dan kesihatan mental. Sehubungan dengan itu, Persatuan Peguam Syarie Malaysia (PGSM) telah memohon mahkamah syariah dan firma peguam syarie di seluruh negara dibenarkan beroperasi kerana ia menjadi institusi penting dan perlu kepada masyarakat merujuk permasalahan mereka. Justeru, bermula 10 Jun 2020, Majlis Keselamatan Negara (MKN) telah membenarkan pengoperasian mahkamah seperti biasa dengan SOP yang ditetapkan apabila kerajaan mengumumkan Perintah Kawalan Pergerakan Bersyarat (PKPB) digantikan dengan Perintah Kawalan Pergerakan Pemulihan (PKPP). Oleh itu, Jabatan Kehakiman Syariah Malaysia (JKSM) telah bertindak menyelaraskan SOP pengoperasian dan menyerahkan kepada kerajaan negeri masing-masing.

\section{Analisis Pengoperasian Mahkamah Syariah Secara Atas Talian}

Hasil penelitian terhadap urusan mahkamah syariah yang dilaksana dalam talian didapati telah merealisasikan maqasid penjagaan keturunan dengan membendung perceraian yang tidak dirujuk kepada mahkamah dan tidak didaftarkan. Ia sekaligus memberi kesan kepada kedudukan institusi keluarga muslim serta autoriti badan kehakiman dan perundangan syariah yang mendukung syiar Islam. Selain itu, ia turut merealisasikan prinsip alIstihssān dengan menjaga kepentingan dan maslahah masyarakat untuk segera bebas daripada impak psikologi yang menimbulkan gangguan terhadap kehidupan seharian akibat penangguhan prosedur undangundang. Bukan itu sahaja, ianya malah telah merealisasikan prinsip Sadd al-Dharì'ah dengan membendung penularan pandemik Covid-19 menggunakan alternatif teknologi moden yang paling sesuai dan berkesan.

\section{Pengehadan Operasi Premis Perniagaan Dan Makanan Mengikut Prosedur Operasi Standard (SOP)}

Kesan Perintah Kawalan Pergerakan fasa 1.0 telah meninggalkan kesan ekonomi yang amat besar kepada negara. Kehidupan rakyat juga akan turut terjejas disebabkan oleh peningkatan jumlah individu yang kehilangan pekerjaan. Menurut Tan Sri Muhyiddin Yassin, Perdana Menteri ketika itu, implikasinya kerajaan terpaksa berbelanja sejumlah RM340 bilion 
Masyitah binti Mohd Zainon, Ahmad Hussein Abdulshakoor Siraji, Mohamed 36 Fathy Mohamed Eletrebi

dengan enam pakej rangsangan bagi membantu rakyat yang terjejas. ${ }^{3}$ Menurut Menteri Kewangan, Tengku Datuk Seri Zafrul Tengku Abdul Aziz dianggarkan jumlah pengangguran dalam kalangan rakyat mencecah satu juta orang, malah negara juga telah menanggung kerugian pada setiap hari lebih kurang RM2.4 bilion. ${ }^{4}$

Ketika itu, semua premis perniagaan dilarang beroperasi kecuali premis yang menjual barang keperluan harian seperti pasar raya, pasar awam, kedai runcit dan kedai serbaneka. Keputusan ini berikutan kerajaan memandang serius peningkatan kes Covid-19 dengan jumlah keseluruhan sebanyak 553 orang. Lanjutan daripada itu, pada 01 April 2020 semua premis perniagaan yang menjual barang keperluan asas dan komoditi telah dihadkan waktu operasi bermula jam 8 pagi hingga 8 malam dengan ditetapkan hanya seorang individu sahaja yang boleh berada dalam kenderaan ketika menjalankan urusan pembelian barangan. Sebaliknya semua pasar malam, pasar pagi dan pasar tani tidak lagi dibenarkan operasi. Bagi memastikan rakyat tidak terkesan teruk dengan langkahlangkah yang diambil oleh kerajaan, bermula 04 Mei 2020 kerajaan mula membenarkan pengoperasian premis makanan secara dine-in di mana sebelum ini penjualannya hanya terhad kepada kaedah bungkusan. Walau bagaimanapun, pengusaha premis mesti melaksanakan penjarakan sosial, menyediakan penyukat suhu badan, mencatat butiran pelanggan dan tidak membenarkan lebih empat pelanggan berada di satu-satu meja. Malangnya, menerusi Prosedur Operasi Standard SOP baharu tersebut, masih terdapat pengusaha-pengusaha premis perniagaan dan makanan yang dikompaun kerana ingkar SOP Perintah Kawalan Pergerakan (PKP).

\section{Analisis Pengehadan Operasi Premis Perniagaan Dan Makanan Mengikut Prosedur Operasi Standard (SOP)}

Hasil penelitian terhadap kebenaran pengoperasian premis perniagaan dan makanan secara terhad dengan sop yang ketat didapati bahawa langkah ini telah merealisasikan maqasid pemeliharaan harta dengan tidak melakukan penutupan penuh semua premis yang menjana ekonomi kepada negara dan rakyat. Selain itu, barang keperluan asas terutama stok makanan

\footnotetext{
${ }^{3}$ https://www.sinarharian.com.my

${ }^{4}$ https://www.mof.gov.my
} 


\section{Prinsip-Prinsip Perundangan Islam: Konsep Dan Aplikasinya Dalam Pentadbiran Pandemik Covid-19 Di Malaysia}

merupakan keutamaanya rakyat ketika kerajaan mengumumkan larangan menyeluruh pergerakan dan perhimpunan ramai di seluruh negara selama tempoh dua minggu. Adapun terjejasnya sebahagian premis peruncitan dan perusahaan kecil dan sederhana (PKS) seperti tukang gunting, peniaga pakaian dan pengusaha cuci kereta ianya tidak dapat dielakkan kerana mengambil kira maslahah yang lebih besar iaitu pemeliharaan lebih banyak nyawa rakyat daripada risiko ancaman maut jika dijangkiti wabak.

Selain itu, usaha kerajaan ini juga dilihat telah merealisasikan prinsip Sadd al-Dhar'̄ah iaitu dengan mengehadkan kapasiti orang ramai dalam sesebuah premis perniagaan dan makanan termasuk menetapkan waktu operasi bagi mengekang kewujudan kluster baharu jangkitan Covid-19. Bukan itu sahaja malah tindakan kerajaan mengkompaun pemilik premis dan pelanggan yang melanggar SOP telah merealisasikan prinsip Ibțāl alHiyal bagi memastikan masyarakat tidak mengambil mudah SOP yang ditetapkan.

\section{Penutupan Pusat Pengajian Dan Pelaksanaan Pembelajaran Atas Talian}

Susulan peningkatan kes jangkitan Covid-19, kerajaan mengambil keputusan menutup semua pusat pengajian termasuk taska, sekolah, pusat tahfiz, dan semua universiti awam dan swasta di seluruh negara. Kesan daripada itu, pusat pengajian tidak mempunyai pilihan melainkan melaksanakan kaedah pembelajaran atas talian. Pelbagai platform pembelajaran digital diperkenalkan seperti Google Classroom, Kahoot, Google Hangout Meet, Google Zoom, Microsoft Teams, Facebook live, Whatsapp dan Telegram bagi memastikan kesinambungan pembelajaran. Selain itu, semua peperiksaan seperti Ujian Penilaian Sekolah Rendah (UPSR) dan Pentaksiran Tingkatan Tiga (PT3) telah dibatalkan, manakala peperiksaan Sijil Pelajaran Malaysia (SPM) dan Sijil Tinggi Persekolahan Malaysia (STPM) telah ditangguhkan. Penutupan pusat pengajian ini adalah bermula Mac 2020 sehingga ia diumumkan untuk dibuka semula secara berperingkat mulai 24 Jun 2020.

Namun demikian, susulan peningkatan semula kes di seluruh negara pada Oktober dan awal November, kerajaan sekali lagi mengumumkan penutupan semula pusat pengajian mulai 09 November 2020 pada ketika rakyat sedang menjalani Perintah Kawalan Pergerakan Bersyarat (PKPB). 
Masyitah binti Mohd Zainon, Ahmad Hussein Abdulshakoor Siraji, Mohamed 38 Fathy Mohamed Eletrebi

Sekalipun hasil kajian yang dijalankan oleh Kementerian Pendidikan Malaysia (KPM) menunjukkan terdapat kekangan di kalangan pelajar kepada akses internet dan penggunaan peranti bagi pembelajaran atas talian, langkah ini terpaksa diambil bagi memutuskan rangkaian Covid-19 yang semakin memburuk. ${ }^{5}$ Ia sekaligus demi memastikan nyawa murid sekolah dan pelajar university tidak terancam.

\section{Analisis Penutupan Pusat Pengajian Dan Pelaksanaan Pembelajaran Atas Talian}

Hasil penelitian terhadap tindakan kerajaan melaksanakan alternatif pembelajaran secara home base learning berhasil merealisasikan maqasid pemeliharaan akal iaitu dengan mengekalkan kepentingan pendidikan kepada rakyat. Kerajaan tetap komited menyediakan inisiatif pendidikan yang sewajarkan sekalipun berhadapan kekangan pandemik demi mengutamakan jaminan masa depan rakyat dan negara. Selain itu, kronologis penutupan pusat pengajian adalah merealisasikan prinsip alIn 'it ă $f$ dan al-Inkisyā $f$ dengan membuat penilaian risiko pembukaan pusat pengajian terhadap pelajar-pelajar terutamanya murid-murid sekolah rendah dan menengah yang masih belum menerima vaksinasi penuh. Di samping itu, ia juga telah merealisasikan prinsip al-Istihsānn iaitu menjamin maslahah para pelajar dengan tidak mendedahkan mereka kepada kemungkinan berlakunya jangkitan COVID-19 daripada guru-guru kerana mereka adalah golongan dewasa yang sentiasa terdedah kepada jangkitan disebabkan oleh kepelbagaian tanggungjawab dan peranan lain yang dipikul.

\section{Kesimpulan}

Sebagai kesimpulan, dapatlah dinyatakan bahawa pentadbiran kerajaan Malaysia telah menjalankan amanah dan tanggungjawab kepada rakyat dalam menangani pandemik Covid-19 dengan baik. Semua langkahlangkah yang diputuskan dan dikuatkuasakan melibatkan pelbagai sektor terutamanya sektor yang telah dianalisis adalah berpandukan kepada prinsip-prinsip perundangan Islam secara khususnya dan maqasid syariah

${ }^{5} \mathrm{https}: / /$ www.bernama.com 


\section{Prinsip-Prinsip Perundangan Islam: Konsep Dan Aplikasinya Dalam Pentadbiran Pandemik Covid-19 Di Malaysia}

secara umumnya. Bagi kajian lanjutan, penelitian terhadap aplikasi prinsip-prinsip perundangan Islam terhadap sektor-sektor lain yang tidak dinyatakan adalah amat penting. Ini bagi memastikan rakyat memahami dan mendokong sepenuhnya pentadbiran kerajaan atas dasar ilmu sekaligus tidak mencetuskan halangan kepada peranan kerajaan.

\section{RUJUKAN}

'Abduh, Muḥammad., \& Riḍā, Rasyīd. (t.th.). Tafsīr al-Manār. Kaherah: Țab'at al-Manār.

Abdul Halim Abdul Karim, Nurul Syuhadah Azalan, \& Muhamad Fadlly Ismail. (2021). Tahap Kefahaman Masyarakat Islam Negeri Pahang Terhadap Peranan Maqasid Syariah Dalam Menangani Wabak Covid-19. Jurnal Al-Sirat, 1(19), 151-162. Retrieved From Https://Ejournal.Kuipsas.Edu.My/Index.Php/Qwefqwefq/Article/ View/37

Abū al-Faḍl, Munā., \& al-`Alwānī, Țāhā Jābir. (1413H-2009M). Mafāhīm Mihwariyyah fì al-Manhaj wa al-Manhajiyyah. Kaherah: Dār alSalām.

Abū Jayb, Sa'dī. (1982M). Al-Qāmūs al-Fiqhī. Dimasyq: (t.pt.).

Aḥmad. (t.th.). Al-Musnad. (t.tp.): (t.pt.).

Al-Bardīsī, Zakariyyā. (1389H/1969M). Ușūl al-Fiqh (Cetakan Ke-3.). Kaherah: Dār al-Nahḍah al-'Arabiyyah.

Al-Bukhārī. (t.th.). Șahīh al-Bukhārī. (t.tp.): (t.pt.).

Al-Dausarī, Muslim Bin Muḥammad. (1430H/2009M). Al-Taqdīrāt alSyar'iyyah Wa Atharuhā F̄ al-Taq'id al-Ușūlì Wa al-Fiqhī (Cetakan Pertama). Riyadh: Dār Zidnī.

Al-Fairūz Ābādī, Muhammad Bin Ya'qūb. (t.th.). Al-Qāmūs al-Muhīṭ. (t.tp.): (t.pt.).

Al-Fayyūmī, Aḥmad Bin Muḥammad. (t.th.). Al-Miṣbāḥ al-Munīr. (t.tp.): (t.pt.). 
Masyitah binti Mohd Zainon, Ahmad Hussein Abdulshakoor Siraji, Mohamed 40 Fathy Mohamed Eletrebi

Al-Futūḥ̄i, Ibn al-Najjār. (Ed.). (1418H/1997M). Syarh al-Kaukāb alMunīr al-Musammā Bi Mukhtaṣār al-Tahrīr (Cetakan Pertama.). Riyadh: Maktabat al-'Abīkān.

Al-Ghazālī, Muhammad. (1413H-1992M). Kaif Nata'āmal ma'a alQur'ān (Cetakan Ke-3). Kaherah: Dār al-Wafā’ \& al-Ma'had al'Ālamī li al-Fikr al-Islāmī.

Al-Hillāwī, Muḥammad 'Abd al-'Azīz. (1985M). Fatāwā wa Aqḍiah 'Umar Bin al-Khattāāb. Kaherah: Maktabat al-Qur’ān.

Al-Kamāl ibn al-Humām. (t.th.). Fath al-Qadīr Syarh al-Hidāyah (Cetakan Ke-2.). Beirut: Dār al-Fikr.

Al-Khairabādī, Moḥammad Abū al-Laith. (2004M). Manhajiyyat alTa'āmul Ma'a al-Bu'dain al-Zamān̄i Wa al-Makān̄̄ F̄̄ alSunnah 'Inda al-Muhaddithin. (t.tp.): (t.pt.).

Al-Khațīb al-Baghdādī. (Ed.). (1422H/2001M). Tarīkh Baghdād (Cetakan Petama.). (t.tp.): Dār al-Gharb al-Islāmī.

Al-Mālikī, Burhānuddin Ibn Farhūn. (Ed.). (1986M). Tabșirat al-Ḥkkām Fì Ūsūl al-Aqụiah Wa Manāhij al-Aḥkām. Kaherah: Maktabat alKulliyyāt al-Azhariyyah.

Al-Manjūr, Aḥmad Bin 'Alī. (Ed.). (t.th.). Syarḥ al-Manhaj al-Muntakhab ilā Qawā'id al-Madhhab (Cetakan Pertama). (t.tp.): Dar 'AbdilLāh al-Syinqīị̂̄ Li al-Nasyr Wa al-Tabā'ah Wa al-Tauzī'.

Al-Mardāwī. (Ed.). (t.th.). Al-Inșāf F̄̄ Ma'rifaț al-Rājiḥ Min al-Khilāf. (t.tp.): Dār Ihyā̄ al-Turāth al-'Arabī.

Al-Mu’jam al-Wasìt . (t.th.). (t.tp.): (t.pt.).

Al-Mudawwanah al-Kubrā. (Ed.). (1994M). (Cetakan Pertama.). Beirut: Dār al-Kutub al-'Ilmiyyah.

Al-Muqrī, Abū 'AbdilLāh. (Ed.). (t.th.). Al-Qawā'id. Mekah: Ma'ahad alBuhūth al-'Ilmiyyah \& Iḥyā' al-Turath al-Islāmī Universiti Umm al-Qurā. 


\section{Prinsip-Prinsip Perundangan Islam: Konsep Dan Aplikasinya Dalam Pentadbiran Pandemik Covid-19 Di Malaysia}

Al-Qarāfī. (t.th.). Al-Furūq. Kaherah: Maṭba'ah 'Īsā al-Ḥalabī.

Al-Rāzī. (1981M). Mukhtār al-Ṣiḥāḥ. Beirut: Dār al-Fikr.

Al-Sanūs̄̄, 'Abd al-Raḥmān Mu'ammar. (1424H). I'tibār al-Ma ālāt Wa Murā'at Natā ij al-Tașarrufāt (Cetakan Pertama.). Dammam: Dār Ibn al-Jauzī.

Al-Sarkhasī. (1324H). Al-Mabsūṭ. Mesir: Maṭba'aț al-Sa'ādah.

Al-Syāț̣ib̄i, Ibrāhīm Bin Mūsā. (t.th.). Al-I'tișām. Beirut: Dār al-Ma'rifah.

Al-Syātịīi, Ibrāhīm Bin Mūsā. (Ed.). (t.th.). Al-Muwāfaqāt. Beirut: Dār alMa'rifah.

Al-Ṭabarī. (1415H-1995M). Jāmi' al-Bayān 'an Ta 'wìl Aȳ̄ al-Qur'ān. Ṭab’at Makkat al-Mukarramah Maktabah Nizār Muștafā al-Bāz.

Al-Ṭabarī. (1422H). Tārīkh al-Umam wa al-Mulūk. Beirut: Dār al-Kutub al-'Ilmiyyah.

Al-Tajdīd F̄̄ 'Ilm Ușūl al-Fiqh al-Sunn̄̄ F̄̄ al-'Așr al-Hadīth Baina alNazariyyah Wa al-Taṭbīq. (2010M). Kaherah: Dār al-'Ulūm.

Al-Walātī, Muḥammad Yaḥyā. (t.th.). Al-Dalil al-Mahir al-Naṣiḥ. Mauritania: Nouakchott.

'Āsyūr, Majdī. (2007M). Al-Sunan al-Ilahiyyah fì al-Umam wa al-Afrād fī al-Qur'ān al-Karīm Ușūl wa Dawābiț (Cetakan Pertama). Kaherah: Dār al-Salām.

Bābā'ammī, Muḥammad Bin Mūsā. (2000M). Mafhūm al-Zaman fĩ alQur'ān (Cetakan Pertama). Beirut: Dār al-Gharb al-Islāmī.

Biltājīi, Muḥammad. (1420H). Manāhij al-Tasyrī’ fì al-Qarn al-Thān̄̄ alHijrī (Cetakan Ke-2). Kaherah: Maktabat al-Balad al-Amīn alAzhar.

Biltājī, Muḥammad. (1998M). Manhaj 'Umar Bin al-Khațtāb fí al-Tasyrì'. Kaherah: Maktabat al-Syabāb. 
Masyitah binti Mohd Zainon, Ahmad Hussein Abdulshakoor Siraji, Mohamed 42 Fathy Mohamed Eletrebi

Hamīdān, Ziyād. (1425H/2004M). Maqāṣid al-Syar'iyyah (Cetakan Pertama.). (t.tp.): Muassasat al-Risālah Nāsyirūn.

Ḥamīdān, Ziyād. (1427H/2006M). Al-Mu'jam al-Jāmi' Li al-Ta'rîfāt alUșūliyyah (Cetakan Pertama.). (t.tp.): Muassasat al-Risālah Nāsyirūn.

Ibn 'Abd al-Barr. (Ed.). (1414H). Jāmi' Bayān al- 'Ilm wa Faḍlih (Cetakan Pertama). Dammam, Arab Saudi: Dār Ibn al-Jauzī.

Ibn al-Athīr. (1415H-1995M). Al-Kāmil f̄i al-Tārīkh. Beirut: Dār Șādir.

Ibn Mājah. (Ed.). (t.th.). Sunan Ibn Mājah. (t.tp.): Dār Ihyā’ al-Kutub al'Arabiyyah - Faișal 'Isā al-Bābī al-Ḥalabī.

Ibn Manẓūr. (t.th.). Lisān al-`Arab. Kaherah: Dār al-Ma’ārif.

Ibn al-Qayyim. (Ed.). (1973M). I'lām al-Muwaqqi'īn 'an Rabb al'Ālamīn. Beirut: Dār al-Jīl.

Ibn al-Qayyim. (1412H-1991M). Madārij al-Sālikīn Baina Manāzil Iyyāka Na'budu wa Iyyāka Nasta'īn. Beirut: Dār al-Jīl.

Ibn Rusyd. (t.th.). Bidāyaț al-Mujtahid Wa Nihāyaț al-Muqtașid. Beirut: Dār al-Kutub al-'Ilmiyyah.

Izzudin, Aplikasi Qawaid Fiqhiyyah Dalam Menghadapi Covid 19, https://insla.usim.edu.my/index.php/eproceeding/article/view/17/ 55. 2020

Jaḥ̄isy, Basyīr Maulūd. (1424H). Al-Ijtihād al-Tanzīlī: Kitāb al-Ummah (Cetakan Pertama.). Doha: Kementerian Awqaf Qatar.

Juma'ah, ‘Alī. (1417H-1996M). Al-Madkhal (Cetakan Pertama). Kaherah: Al-Ma'had al-‘'Âlamī li al-Fikr al-Islāmī.

Mālik Bin Anas. (t.th.). Al-Muwațțā'. (t.tp.): (t.pt.)

Mālik Bin Nabī. (Terj.). (2000M). Syurūt al-Nahdah (Cetakan Ke-5). Dimasyq: Dār al-Fikr al-Mu'āṣir.

Musnad al-Imam Aḥmad. (t.th.). (t.tp.): (t.pt.). 


\section{Prinsip-Prinsip Perundangan Islam: Konsep Dan Aplikasinya Dalam Pentadbiran Pandemik Covid-19 Di Malaysia}

Nur Hidayat, Sekatan Pergerakan Berdepan Covid-19 Di Malaysia: Satu Tinjauan Dari Perspektif Islam (Movement Restrictions Confronting Covid-19 In Malaysia: An Overview From Islamic Perspective). 2020

Qal'ah Jī, Muḥammad Rawwās. (1996M). Mu'jam Lughat al-Fuqahā' (Cetakan Pertama.). Beirut: Dār al-Nafā̀ is.

Rabī', 'AbdulLāh. (2007M). Al-Istihsān Wa Hujjiyyatuhu 'Inda alUșūliyȳin (Cetakan Pertama.). Kaherah: Dār al-Salām.

Rab, Muneer, THE FIQH PRINCIPLES GOVERNING (COVID-19): EMERGING ISSUES IN PRAYERS AND PURITY. 2020/11/16

Riụā, Rasȳ̄d. (1352H). Al-Wahyy al-Muhammadī. Mesir: Ṭab'at al-Manār.

Syalabī, Muștafāa. (t.th.). Ta'līl al-Aḥkām (Cetakan Ke-2). Kaherah: Dār al-Nahḍat al-'Arabiyyah. 